\title{
Fear of COVID-19 changes economic preferences: evidence from a repeated cross-sectional MTurk survey
}

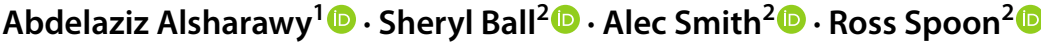

Received: 15 December 2020 / Revised: 5 November 2021 / Accepted: 10 November 2021 /

Published online: 4 December 2021

(c) The Author(s), under exclusive licence to Economic Science Association 2021

\begin{abstract}
The personal experience of events such as financial crises and natural disasters can alter economic preferences. We administered a repeated cross-sectional preference survey during the early stages of the COVID-19 outbreak, collecting three bi-weekly samples from participants recruited through Amazon Mechanical Turk. The survey elicits economic preferences, self-reported fear of the pandemic, and beliefs about economic and health consequences. Preferences varied over time and across regions, and self-reported fear of the pandemic explains this variation. These findings suggest caution about the generalizability of some types of experimental work during times of heightened fear.
\end{abstract}

Keywords COVID-19 $\cdot$ Economic preferences $\cdot$ Risk $\cdot$ Time preferences $\cdot$ Fear

JEL Classification D91 · H59 · I19

\section{Introduction}

The COVID-19 pandemic has had significant economic and social impacts, including increased fear and anxiety (Coelho et al., 2020; Lee et al., 2020). We explore the effect of COVID-19 on economic preferences in the United States using an online survey that includes preference measures from the Global Preference Survey (GPS) (Falk et al., 2016, 2018), self-reports of fear, and other measures. By exploiting temporal and geographic variation in disease prevalence, we show that fear of the pandemic is closely linked with changes in economic preferences.

Although a central tenet of economic modeling is that preferences are stable (Stigler \& Becker, 1977), a number of recent studies demonstrate how they are shaped

Alec Smith

alecsmith@vt.edu

1 School of Public and International Affairs, Princeton University, Princeton, NJ, USA

2 Department of Economics, Virginia Tech, Blacksburg, VA, USA 
by experience. Risk preferences, for example, are affected by financial crises (Guiso et al., 2018; Malmendier \& Nagel, 2011), earthquakes (Hanaoka et al., 2018), hurricanes (Eckel et al., 2009), tsunamis (Cassar et al., 2017), and violent attacks (Callen et al., 2014). Time preferences are also affected by earthquakes (Beine et al., 2020; Callen, 2015). In social behavior, Positive reciprocity changed after the 2004 Indian Ocean tsunami and the 2010 Chilean earthquake (Cassar et al., 2017; Fleming et al., 2014), while contributions to public goods increased after hurricanes (Whitt \& Wilson, 2007).

This project was motivated in part by academic discussions about whether data collected during the COVID-19 outbreak were reliable. We find that specific economic preferences varied systematically with self-reported fear during the early weeks of the pandemic. Our results are consistent with previous findings and highlight the importance of personal experience (with crises such as the pandemic) in shaping economic preferences.

\section{Methods}

Data were collected using participants recruited through Amazon Mechanical Turk (MTurk), a crowdsourcing platform connecting businesses and researchers to workers who complete virtual tasks. The target sample size for each wave was 500 participants currently residing in the United States. The survey included 60 questions (plus five attention check questions) measuring:

1. individual and socioeconomic characteristics (20 questions),

2. economic preferences including Risk, Time, Altruism, and Positive and Negative reciprocity (from the GPS, Falk et al., 2016, 2018) (12 questions),

3. (unincentivized) lottery choice (Eckel \& Grossman, 2002) (1 question),

4. trust in people and institutions (adapted from the GPS, the World Values Survey (WVS) [Inglehart et al., 2004), and the German Socio-Economic Panel Study (GSOEP) (Wagner et al., 2007)] (9 questions),

5. emotions experienced after people/institutions make decisions in response to a crisis (4 questions), and

6. behavior and beliefs regarding the COVID-19 pandemic (14 questions).

The questions regarding COVID-19 included measures of beliefs about the pandemic's impact on the health and financial well-being of the respondents' household, and the respondents' fear of the pandemic. The full list of questions is provided in the Supplementary Materials.

We first investigate the drivers of fear of the COVID-19 pandemic (question 60 from our survey, see the supplement). While we developed this survey prior to the development of the fear of COVID-19 scale (FCV-19S), our fear of COVID-19 question is similar to an FCV-19S item with a strong factor loading (Ahorsu et al., 2020). We then examine how economic preferences covaried with fear of the disease and its local incidence. 
We obtained county-level data on population and COVID-19-related deaths from the COVID-19 Data Repository by the Center for Systems Science and Engineering (CSSE) at Johns Hopkins University (https://github.com/CSSEGISandData/ COVID-19) (Dong et al., 2020). Participant ZIP codes were matched to counties using a free ZIP code database (www.unitedstateszipcodes.org/zip-code-database). This study was approved by Virginia Tech's Institutional Review Board. Participants provided informed consent, received $\$ 2$ compensation, and took on average around 20 min to complete the survey. We sampled participants without replacement via MTurk beginning April 2nd, 2020, in three roughly 2-week intervals. As of the first wave of data collection, which lasted 3 days, there were over 250,000 confirmed cases of COVID-19 in the US, with more than 8000 confirmed deaths. The second wave of the survey lasted 4 days starting on April 16th, when the number of confirmed cases in the US surpassed 600,000 with close to 37,000 deaths. Responses for the third wave were collected in 1 day, April 30th, when US cases surpassed 1 million and deaths surpassed 66,000 (Dong et al., 2020). The employment level in the U.S. declined from 158.7 to 155.5 million between February and March, 2020 before deteriorating significantly to 133.7 million in the following month (U.S. Bureau of Labor Statistics, Employment Level [CE16OV], n.d.).

Table S1 (Supplementary Material) provides summary statistics across the 3 waves of the survey and reports some minor differences in demographics for the third wave. The third wave had a slightly lower number of female respondents, and included participants who were younger, attended religious services more regularly, and reported having lower relative income. We control for these differences in our regression analyses (explained in detail below). During the first wave we restricted participants to those with Masters Qualification (assigned by MTurk to those deemed as high performers and completed numerous tasks). We dropped this requirement for the other waves to ensure enough participation, replacing it with a requirement that targets similarly high performing workers with a $99 \%$ or higher approval rating and at least 5000 approved HITs (Human Intelligence Tasks).

\section{Results}

We investigate how behavioral preferences vary with two measures of exposure to the COVID-19 outbreak: fear (question 60: Are you afraid of the COVID-19 pandemic? 11-point Likert Scale) and the local death rate (LDR) calculated as $100,000 *$ deaths/population in the participant's county, a variable which increased rapidly across waves (Table S1 in the Supplementary Material). Our sample includes respondents from 49 states and 419 counties in the United States. We standardize (z-score) all Likert scale measures at the individual level to account for the possibility that individuals may use different survey scales (Falk et al., 2016, 2018). In contrast to the steep increase in LDR (Difference in means for waves 1-2: - 7.417; waves 1-3: -21.218 , waves 2-3: - 13.801; distributions differ according to ranksum tests, $p<0.001$ for each pairwise comparison) and in COVID-19-related deaths in the U.S. across waves, self-reports of fear declined after wave 1 (Difference in means for waves 1-2: 0.184, waves 1-3: 0.224, waves 2-3: 0.040; rank-sum tests 


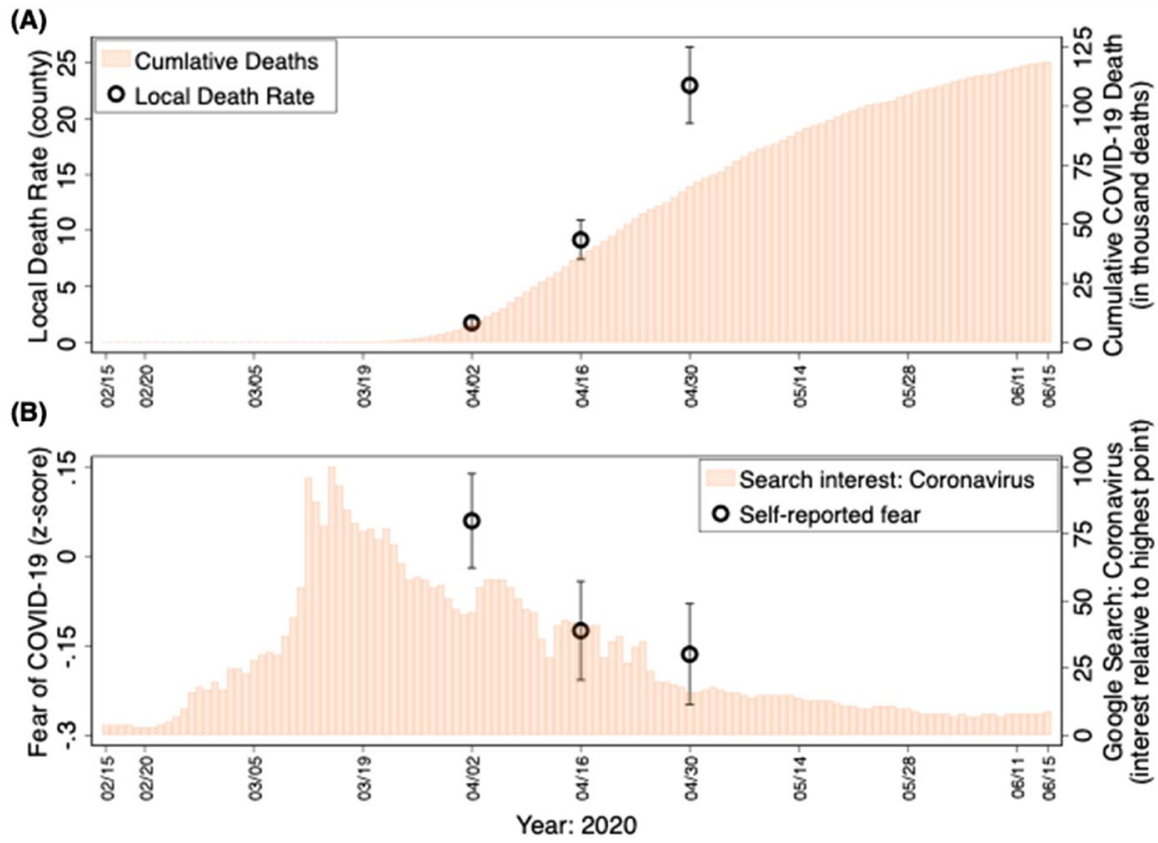

Fig. 1 Time trends in cumulative death rate and general search interest (Google) of the term "Coronavirus" vs. trends in local death rate and self-reported fear of COVID-19 for sample participants. A Rising trend in both average local death rate (county-level) across sample participants (left axis) and cumulative COVID-19 deaths in the U.S. over the course of the month of April 2020. B Declining trend in both average self-reports of fear of COVID-19 for sample participants (left axis) and relative search interest of the term "Coronavirus" in the U.S. (right axis) over the course of the month of April 2020. Number of deaths in the U.S. are obtained from the Data Repository by the Center for Systems Science and Engineering (CSSE) at Johns Hopkins University (Dong et al., 2020), while relative search interest is obtained from Google Trends (https://www.google.com/trends)

for differences in distributions: waves $1-2, p=0.002$; waves $1-3, p<0.001$; waves $2-3, p=0.377$ ) (see Fig. 1 and Table S1). Despite the relatively short gap between waves ( 2 weeks), the decline in fear is consistent with habituation to a stressor (Stein et al., 2018), and with a modest decline in attention to the pandemic (as measured by internet searches) in the US overall over the course of the month of April 2020 (see Fig. 1).

\subsection{Fear of the pandemic}

We explored the drivers of fear using linear fixed-effects regressions that included controls for LDR, individual characteristics, state fixed effects, and survey wave indicators (Table 1). We employed fixed effects on the state level, since the median number of responders by state is 49 compared to a median of only 6 responders on the county level. In subsequent specifications, we control for expectations of financial hardship by computing the first principal component (1st PC) across questions 
Table 1 Regression results for Fear of COVID-19 (pooled sample)

Dependent variable: Fear of COVID-19

\begin{tabular}{|c|c|c|c|c|c|}
\hline & (a) & (b) & (c) & (d) & (e) \\
\hline Local death rate (LDR) & $\begin{array}{l}0.0021 * * \\
(0.0009)\end{array}$ & $\begin{array}{l}0.0015^{*} \\
(0.0009)\end{array}$ & $\begin{array}{l}0.0015^{*} \\
(0.0008)\end{array}$ & $\begin{array}{l}0.0013 \\
(0.0009)\end{array}$ & $\begin{array}{l}0.0015^{*} \\
(0.0008)\end{array}$ \\
\hline Female & $\begin{array}{l}0.1615^{* *} \\
(0.0677)\end{array}$ & $\begin{array}{l}0.1088^{*} \\
(0.0598)\end{array}$ & $\begin{array}{l}0.1099 * \\
(0.0592)\end{array}$ & $\begin{array}{l}0.1028^{*} \\
(0.0595)\end{array}$ & $\begin{array}{l}0.0993^{*} \\
(0.0581)\end{array}$ \\
\hline Good at math & $\begin{array}{l}-0.2114 * * * \\
(0.0334)\end{array}$ & $\begin{array}{l}-0.1441 * * * \\
(0.0343)\end{array}$ & $\begin{array}{l}-0.1449 * * * \\
(0.0328)\end{array}$ & $\begin{array}{l}-0.1496^{* * * *} \\
(0.0326)\end{array}$ & $\begin{array}{l}-0.1564 * * * \\
(0.0333)\end{array}$ \\
\hline Liberal & $\begin{array}{l}0.0766 * * \\
(0.0319)\end{array}$ & $\begin{array}{l}0.0668 * * \\
(0.03)\end{array}$ & $\begin{array}{l}0.0328 \\
(0.0294)\end{array}$ & $\begin{array}{l}-0.0329 \\
(0.0427)\end{array}$ & $\begin{array}{l}-0.0367 \\
(0.047)\end{array}$ \\
\hline Wave 2 & $\begin{array}{l}-0.1936^{* * *} \\
(0.0503)\end{array}$ & $\begin{array}{l}-0.1063 * * \\
(0.0475)\end{array}$ & $\begin{array}{l}-0.1089 * * \\
(0.0463)\end{array}$ & $\begin{array}{l}-0.1083^{* *} \\
(0.0469)\end{array}$ & $\begin{array}{l}-0.0992 * * \\
(0.0458)\end{array}$ \\
\hline Wave 3 & $\begin{array}{l}-0.2279^{* * *} \\
(0.0651)\end{array}$ & $\begin{array}{l}-0.1392^{* *} \\
(0.0642)\end{array}$ & $\begin{array}{l}-0.1402 * * \\
(0.0587)\end{array}$ & $\begin{array}{l}-0.1385^{* *} \\
(0.0579)\end{array}$ & $\begin{array}{l}-0.1391 * * \\
(0.0581)\end{array}$ \\
\hline Perceive financial hardship (1st PC) & - & $\begin{array}{l}0.0359 * * \\
(0.0153)\end{array}$ & $\begin{array}{l}0.0339 * * \\
(0.0167)\end{array}$ & $\begin{array}{l}0.0329 * \\
(0.017)\end{array}$ & $\begin{array}{l}0.0295^{*} \\
(0.017)\end{array}$ \\
\hline Perceive health hardship (1st PC) & - & $\begin{array}{l}0.2703 * * * \\
(0.0147)\end{array}$ & $\begin{array}{l}0.2592 * * * \\
(0.0154)\end{array}$ & $\begin{array}{l}0.2573 * * * \\
(0.0159)\end{array}$ & $\begin{array}{l}0.251 * * * \\
(0.0164)\end{array}$ \\
\hline Trust in government & - & - & $\begin{array}{l}-0.1172 * * * \\
(0.0266)\end{array}$ & $\begin{array}{l}-0.1172 * * * \\
(0.0267)\end{array}$ & $\begin{array}{l}-0.1168 * * * \\
(0.0266)\end{array}$ \\
\hline Trust in media & - & - & $\begin{array}{l}0.0904 * * * \\
(0.0336)\end{array}$ & $\begin{array}{l}0.0842 * * \\
(0.0343)\end{array}$ & $\begin{array}{l}0.0764 * * \\
(0.0336)\end{array}$ \\
\hline Trust in people (1st PC) & - & - & $\begin{array}{l}-0.0079 \\
(0.0141)\end{array}$ & $\begin{array}{l}-0.0083 \\
(0.0141)\end{array}$ & $\begin{array}{l}-0.0019 \\
(0.0136)\end{array}$ \\
\hline Liberal $\times$ Trust in government & - & - & - & $\begin{array}{l}-0.0856^{* *} \\
(0.0332)\end{array}$ & $\begin{array}{l}-0.0796 * * \\
(0.0326)\end{array}$ \\
\hline Liberal $\times$ Trust in media & - & - & - & $\begin{array}{l}-0.0152 \\
(0.0268)\end{array}$ & $\begin{array}{l}-0.0104 \\
(0.027)\end{array}$ \\
\hline Liberal $\times$ Trust in people $(1$ st PC) & - & - & - & $\begin{array}{l}0.0168 \\
(0.0155)\end{array}$ & $\begin{array}{l}0.0147 \\
(0.017)\end{array}$ \\
\hline People engage in physical distancing & - & - & - & - & $\begin{array}{l}-0.129 * * * \\
(0.0439)\end{array}$ \\
\hline $\begin{array}{l}\text { Liberal } \times \text { people engage in physical } \\
\text { distancing }\end{array}$ & - & - & - & - & $\begin{array}{l}0.0053 \\
(0.0621)\end{array}$ \\
\hline Constant & $\begin{array}{l}-0.1633 \\
(0.4006)\end{array}$ & $\begin{array}{l}-0.0563 \\
(0.3662)\end{array}$ & $\begin{array}{l}0.0028 \\
(0.3715)\end{array}$ & $\begin{array}{l}-0.0087 \\
(0.3706)\end{array}$ & $\begin{array}{l}0.0697 \\
(0.3896)\end{array}$ \\
\hline Observations & 1484 & 1484 & 1484 & 1484 & 1484 \\
\hline State fixed effects and additional controls & Yes & Yes & Yes & Yes & Yes \\
\hline R-squared & 0.1048 & 0.2382 & 0.2475 & 0.2528 & 0.2582 \\
\hline
\end{tabular}

Standard errors (clustered at the state level) in parentheses. The dependent variable, fear of COVID-19, is measured in question 60 (Are you afraid of the COVID-19 pandemic?-Supplementary Material). Additional controls included age, age-squared, and indicators for race (Caucasian) and origin (Hispanic), self-reported household income relative to others in community, working full time, education level, smoking behavior, frequency of attending religious services, and parent(s) receiving a bachelor's degree. All Likert scale measures are standardized at the individual level ( $z$-scored). $* * * p<0.01, * * p<0.05$, $* p<0.1$. All tables were created using asdoc, a Stata program written by (Shah, 2020) 
about experienced financial stress, and the likelihood of job or income loss resulting from the pandemic [questions 53 and 56-57: perceive financial hardship (1st PC)]. Similarly, we control for expectations about the likelihood of experiencing health hardships, such as contracting the virus or dying [questions 58-59: perceive health hardship (1st PC)]. In addition, we control for responder's probabilistic beliefs about whether others are engaging in social distancing (question 47), self-reported trust in government (question 40), media (question 41) and people [questions 29 and 35-39 (1st PC)]. In the last model specification (Table 1e), we also control for beliefs that people engage in social distancing (question 47) and the interaction between our trust measures with political affiliation. In this specification that includes all belief and trust controls, we again confirm that self-reported fear declined in waves 2 and 3 relative to wave $1\left(\beta_{\text {wave } 2}=-0.099, p=0.035 ; \beta_{\text {wave } 3}=-0.139, p=0.021\right.$; Table 1e). The decline in fear across waves holds when we omit the LDR as a control variable (result available upon request).

Fear was positively and significantly associated with $\operatorname{LDR}\left(\beta_{L D R}=0.002\right.$, $p=0.021$; Table 1a), with the association weakening after adding controls for perceptions of financial and health hardships $\left(\beta_{L D R}=0.002, p=0.080\right.$; Table $\left.1 \mathrm{~b}\right)$. Females reported higher fear $\left(\beta_{\text {Female }}=0.161, p=0.021\right.$; Table $1 \mathrm{a}$; confirmed in a withinsubject university sample using data collected in Fall 2019 and on April 2, 2020, Table S8 in the Supplementary Material), with the association again weakening when we control for perceptions of financial and health hardships $\left(\beta_{\text {Female }}=0.109\right.$, $p=0.075$; Table $1 \mathrm{~b}$ ), as women perceived stronger health risks from the pandemic than men (Alsharawy et al., 2021). Moreover, participants with higher cognitive ability, measured by reporting "good at math" (question 30, Supplementary Material), were more likely to report lower levels of fear $\left(\beta_{\text {Good at math }}=-0.211\right.$, $p<0.001$; Table 1a; result holds with additional controls). Unsurprisingly, Perceptions of health hardships and financial hardships due to COVID-19 were positively and significantly associated with fear of COVID-19 $\left(\beta_{\text {Expecthealth hardship }}=0.270\right.$, $p<0.001 ; \beta_{\text {Expect financial hardship }}=0.036 p=0.023$; Table $1 \mathrm{~b}$ ), with the latter association weakening when we control for other beliefs $\left(\beta_{\text {Expect health hardship }}=0.251\right.$, $p<0.001 ; \beta_{\text {Expectfinancial hardship }}=0.029, p=0.090$; Table 1e). This result, however, did not extend to our university sample (Supplementary Material).

We also find a link between political affiliation and fear of the pandemic, consistent with recent work connecting responses to the pandemic to political partisanship (Allcott et al., 2020; Barrios \& Hochberg, 2020; Gadarian et al., 2021; Painter \& Qiu, 2020). Our sample responders were more skewed toward liberal, with about $58 \%$ providing a Likert response greater than 5 when asked to self-describe their political orientation (question 21) using a scale from 0 (complete conservative) to 10 (complete liberal). Stronger self-identification as politically liberal was positively and significantly associated with fear of the pandemic $\left(\beta_{\text {Liberal }}=0.077, p=0.020\right.$; Table 1a). Note that the survey was administered during the Republican presidential administration of Donald Trump, a time when trust in the government was near an all-time low (Public Trust in Government: 1958-2021, 2021). Interestingly, the relation between fear of COVID-19 and political orientation vanishes when controlling for trust in government, media and people $\left(\beta_{\text {Liberal }}=0.033, p=0.270\right.$; Table 1c $)$ and their interactions with political orientation $\left(\beta_{\text {Liberal }}=-0.033, p=0.445\right.$; Table $\left.1 \mathrm{~d}\right)$. 
Fear negatively covaried with trust in the government $\left(\beta_{\text {Trust in government }}=-0.117\right.$, $p<0.001$; Table 1c), and liberal orientation strengthened this negative association $\left(\beta_{\text {Liberal } \times \text { Trust in government }}=-0.086, p=0.013\right.$; Table $\left.1 \mathrm{~d}\right)$. The negative relationship between trust in government and self-reported fear was marginally significant using our university panel data set (Supplementary Material). Our survey question (question 40: agreement with "Government can generally be trusted") did not distinguish between trust in local, state, or national governments. Nevertheless, the results demonstrate that fear of the pandemic was negatively linked to overall trust in government. On the other hand, trusting the media (question 41) predicted fear $\left(\beta_{\text {Trust in media }}=0.084, p=0.018\right.$; Table $\left.1 \mathrm{~d}\right)$, which may be due to stronger mediadriven awareness of the pandemic. Trust in media, however, did not systematically vary with fear of COVID-19 in our university sample (Supplementary Material).

We next examine how fear covaried with trust in other people (rather than government or the media). Here, trust in people was computed as the first principal component across survey questions that elicit agreement with phrases, such as "I assume that people have only the best intentions" and "people can generally be trusted" [questions 29 and 35-39, adapted from the GPS, WVS, and GSOEP (Falk et al., 2016, 2018; Inglehart et al., 2004; Wagner et al., 2007)]. ${ }^{1}$ Though trusting other people was also not significantly associated with fear, as shown in Table 1e, stronger beliefs that people engage in social distancing were robustly associated with lower self-reported fear ( $\beta_{\text {People engage in physical distancing }}=-0.129, p=0.005$; Table 1e; similar finding among the university sample, see Supplementary Material). Taken together, these results support the conclusion that trust in institutions and in people's actions mitigated fear of the pandemic.

\subsection{Economic preferences and the pandemic}

To investigate the relation between economic preferences, fear of COVID-19, and LDR, we rely again on linear fixed-effects regressions. We control for individual characteristics and state fixed effects in the pooled sample and in each wave separately. In the regression specifications reported in Tables 2, 3, 4, 5, and 6, we also control for perceptions of financial and health hardships (risk perception) that may be one factor driving affective responses (Loewenstein et al., 2001). In the Supplementary Materials, we also test a specification that replaces our fear survey measure with a generalized factor variable that accounts for the overall intensity of experiencing the pandemic by computing the first principal component across our fear measure (question 60) and the perceptions of financial (questions 53 and 56-57) and health (questions 58-59) hardships (Tables S3-S7).

\footnotetext{
1 A recent study shows that people living in areas of Italy harder hit by the virus trusted strangers more (Gambetta \& Morisi, 2020). Other results from early in the pandemic are mixed, with trust increasing in Sweden (Esaiasson et al., 2021) and decreasing in Wuhan, China (Shachat et al., 2021). In our data, trust in people was greater in the later waves $\left(\beta_{\text {Wave } 2}=0.210, p=0.015 ; \beta_{\text {Wave } 3}=0.390, p<0.001\right.$; Table S2). In contrast to Gambetta \& Morisi (2020), we do not find a statistically significant association between trust in people and the local death rate (Table S2).
} 


\subsubsection{Risk preference}

To measure Risk tolerance, we asked participants about their general willingness to take risks (question 22), an approach that has been validated against incentivized measures of risk aversion (Dohmen et al., 2011; Falk et al., 2016, 2018). In addition, we measured risk preferences using an (unincentivized) lottery choice task (question 32) (Eckel \& Grossman, 2002). Our Risk tolerance measure is computed as the first principal component (1st PC) of these two measures. Fear of the pandemic was negatively and significantly associated with Risk tolerance (pooled sample: $\beta_{\text {Afraid }}=-0.188, p<0.001$, Table 2 ), and was robust after we controlled for multiple hypothesis tests (Anderson, 2008) for the effect of either fear of COVID-19 or LDR (sharpened $q$ value $=0.005$ ). The association was weaker in the third wave of our survey (wave 1: $\beta_{\text {Afraid }}=-0.201, p=0.007$; wave 2: $\beta_{\text {Afraid }}=-0.219, p=0.005$; wave $3: \beta_{\text {Afraid }}=-0.149, p=0.056$; sharpened $q$ value for wave $3=0.122$ ). Importantly, this negative Risk tolerance-fear association was confirmed for the generalized measure of the intensity of experiencing the pandemic, and in the university sample (Supplementary Material; Tables S9-S11). This finding is consistent with the uniformly lower Risk tolerance reported in a Chinese student sample after the pandemic's onset (Bu et al., 2020). Interestingly, LDR was not significantly associated with Risk tolerance, demonstrating that fear, but not local exposure to the pandemic, was closely linked to Risk tolerance.

\subsubsection{Time preference}

To elicit time preferences (question 23), we asked participants about their willingness to give up a reward today to earn a larger reward in the future. This question has also been validated against incentivized measures of time preferences (Falk et al., 2016, 2018). Increased fear of the COVID-19 pandemic was significantly and negatively associated with patience in the pooled sample and across the first two waves of our survey (marginally associated in the third wave) (pooled sample: $\beta_{\text {Afraid }}=-0.092, p<0.001$; wave 1: $\beta_{\text {Afraid }}=-0.129, p=0.006$; wave $2: \beta_{\text {Afraid }}$ $=-0.069, p=0.035$; wave 3: $\left.\beta_{\text {Afraid }}=-0.088, p=0.063\right)($ Table 3$){ }^{2}$ This result, which remained significant in the pooled sample after accounting for multiple testing (sharpened $q$ value $=0.007$ ) is consistent with studies demonstrating that time preference varies with emotions: patience increases with positive affect (Ifcher \& Zarghamee, 2011), and gratitude (DeSteno et al., 2014), and decreases with negative affect, such as sadness (Lerner et al., 2012). ${ }^{3}$ This robust association between

\footnotetext{
${ }^{2}$ We also find a negative association between patience and our generalized measure of the intensity of experiencing the pandemic (see the supplementary material).

3 Patience and LDR covaried positively in the regression (after controlling for fear), though only in our pooled sample $\left(\beta_{L D R}=0.001, p=0.004\right.$, sharpened $q$-value $\left.=0.026\right)$. While LDR is positively linked with fear (see Table 1), this positive association between patience and LDR could be related to differences in geographic exposure to the pandemic.
} 
Table 2 Regression results (Risk)

Dependent variable: Risk tolerance

\begin{tabular}{|c|c|c|c|c|}
\hline & (a) & (b) & (c) & (d) \\
\hline & Pooled & Wave1 & Wave2 & Wave3 \\
\hline Afraid of COVID-19 & $\begin{array}{l}-0.1875^{* * *} \\
(\mathbf{0 . 0 4 5 3 )}\end{array}$ & $\begin{array}{l}-0.201 * * * \\
(0.0709)\end{array}$ & $\begin{array}{l}-0.219 * * * \\
(0.0733)\end{array}$ & $\begin{array}{l}-0.1488^{*} \\
(0.0759)\end{array}$ \\
\hline Local death rate (LDR) & $\begin{array}{l}0.0019 \\
(0.0014)\end{array}$ & $\begin{array}{l}-0.0079 \\
(0.0053)\end{array}$ & $\begin{array}{l}0.0004 \\
(0.0019)\end{array}$ & $\begin{array}{l}0.0022 \\
(0.0017)\end{array}$ \\
\hline Perceive financial hardship (1st PC) & $\begin{array}{l}-0.0157 \\
(0.0281)\end{array}$ & $\begin{array}{l}-0.0827 * \\
(0.043)\end{array}$ & $\begin{array}{l}0.0067 \\
(0.0469)\end{array}$ & $\begin{array}{l}0.0249 \\
(0.0501)\end{array}$ \\
\hline Perceive health hardship (1st PC) & $\begin{array}{l}0.0139 \\
(0.033)\end{array}$ & $\begin{array}{l}0.011 \\
(0.0549)\end{array}$ & $\begin{array}{l}0.0598^{*} \\
(0.0344)\end{array}$ & $\begin{array}{l}-0.0372 \\
(0.0609)\end{array}$ \\
\hline Female & $\begin{array}{l}-0.4454^{* * *} \\
(0.0907)\end{array}$ & $\begin{array}{l}-0.4777^{* * * *} \\
(0.1345)\end{array}$ & $\begin{array}{l}-0.328^{* * *} \\
(0.1212)\end{array}$ & $\begin{array}{l}-0.5753^{* * *} \\
(0.0882)\end{array}$ \\
\hline Good at math & $\begin{array}{l}0.064 \\
(0.0488)\end{array}$ & $\begin{array}{l}0.0337 \\
(0.0754)\end{array}$ & $\begin{array}{l}0.098 \\
(0.0586)\end{array}$ & $\begin{array}{l}0.0764 \\
(0.0633)\end{array}$ \\
\hline Liberal & $\begin{array}{l}-0.0032 \\
(0.0355)\end{array}$ & $\begin{array}{l}0.0165 \\
(0.0515)\end{array}$ & $\begin{array}{l}0.0149 \\
(0.0456)\end{array}$ & $\begin{array}{l}-0.003 \\
(0.0629)\end{array}$ \\
\hline Wave 2 & $\begin{array}{l}0.0429 \\
(0.0534)\end{array}$ & - & - & - \\
\hline Wave 3 & $\begin{array}{l}0.0149 \\
(0.0711)\end{array}$ & - & - & - \\
\hline Constant & $\begin{array}{l}-0.3197 \\
(0.4437)\end{array}$ & $\begin{array}{l}-0.7301 \\
(0.5894)\end{array}$ & $\begin{array}{l}-0.163 \\
(0.6042)\end{array}$ & $\begin{array}{l}-0.4295 \\
(0.5324)\end{array}$ \\
\hline Observations & 1484 & 488 & 499 & 497 \\
\hline State fixed effects and additional controls & Yes & Yes & Yes & Yes \\
\hline R-squared (within) & 0.123 & 0.1489 & 0.1265 & 0.157 \\
\hline
\end{tabular}

Standard errors (clustered at the state level) in parentheses. The dependent variable, Risk tolerance, is computed as the first principal component across questions 22 (willingness to take risks) and 32 (lottery choice) (Supplementary Material). Additional controls included age, age-squared, and indicators for race (Caucasian) and origin (Hispanic), self-reported household income relative to others in community, working full time, education level, smoking behavior, frequency of attending religious services, and parent(s) receiving a bachelor's degree. All Likert scale measures are standardized at the individual level (z-scored). $* * * p<0.01, * * p<0.05, * p<0.1$ (bold values indicate significant coefficient upon computing sharpened $q$ values accounting for multiple tests on Afraid of COVID-19 and LDR: $q<0.05$ )

patience and fear again demonstrates the link between affective responses and economic preferences. Our results are also consistent with findings that the effects of the same significant event can vary across sub-groups and individuals (Alsharawy et al., 2021; Callen et al., 2014; Eckel et al., 2009; Huang et al., 2013; Ibuka et al., 2010; Jang et al., 2020; Taylor et al., 2008). The effects of the pandemic on time preferences may have operated through multiple channels, including individual affective responses to the outbreak and local differences in disease prevalence. 
Table 3 Regression results (Time preference)

Dependent variable: Patience

\begin{tabular}{|c|c|c|c|c|}
\hline & (a) & (b) & (c) & (d) \\
\hline & Pooled & Wave 1 & Wave2 & Wave3 \\
\hline \multirow[t]{2}{*}{ Afraid of COVID-19 } & $-0.0916 * * *$ & $-0.1294 * * *$ & $-0.0695^{* *}$ & $-0.0884^{*}$ \\
\hline & $(0.0242)$ & $(0.0454)$ & $(0.032)$ & $(0.0464)$ \\
\hline \multirow[t]{2}{*}{ Local death rate (LDR) } & $0.0012 * * *$ & -0.0002 & 0.0001 & $0.0011 *$ \\
\hline & $(0.0004)$ & $(0.0069)$ & $(0.0011)$ & $(0.0006)$ \\
\hline \multirow[t]{2}{*}{ Perceive financial hardship (1st PC) } & $-0.0526 * * *$ & $-0.069 * * *$ & $-0.058 * *$ & -0.0246 \\
\hline & $(0.0143)$ & $(0.0236)$ & $(0.0249)$ & $(0.0232)$ \\
\hline \multirow[t]{2}{*}{ Perceive health hardship (1st PC) } & 0.0056 & 0.036 & -0.0036 & -0.0266 \\
\hline & $(0.015)$ & $(0.0287)$ & $(0.0212)$ & $(0.0298)$ \\
\hline \multirow[t]{2}{*}{ Female } & -0.0543 & -0.078 & -0.0957 & -0.0332 \\
\hline & $(0.0462)$ & $(0.0783)$ & $(0.0633)$ & $(0.0506)$ \\
\hline \multirow[t]{2}{*}{ Good at math } & $0.0451 * *$ & 0.0415 & 0.0451 & 0.0367 \\
\hline & $(0.0184)$ & $(0.0418)$ & $(0.0304)$ & $(0.0238)$ \\
\hline \multirow[t]{2}{*}{ Liberal } & -0.0116 & 0.007 & 0.0188 & $-0.0748 * *$ \\
\hline & $(0.0208)$ & $(0.0464)$ & $(0.0343)$ & $(0.0314)$ \\
\hline \multirow[t]{2}{*}{ Wave 2} & -0.0307 & - & - & - \\
\hline & $(0.036)$ & & & \\
\hline \multirow[t]{2}{*}{ Wave 3} & 0.0078 & - & - & - \\
\hline & $(0.0349)$ & & & \\
\hline \multirow[t]{2}{*}{ Constant } & $0.5582 * *$ & 0.3095 & 0.2838 & $0.9058 * * *$ \\
\hline & $(0.231)$ & $(0.394)$ & $(0.4093)$ & $(0.3316)$ \\
\hline Observations & 1484 & 488 & 499 & 497 \\
\hline State fixed effects and additional controls & Yes & Yes & Yes & Yes \\
\hline R-squared (within) & 0.0819 & 0.1005 & 0.0932 & 0.1061 \\
\hline
\end{tabular}

Standard errors (clustered at the state level) in parentheses. The dependent variable, patience, is measured in question 23 ("Willingness to give up something that is beneficial for you today in order to benefit more from that in the future"-Supplementary Material). Additional controls included age, age-squared, and indicators for race (Caucasian) and origin (Hispanic), self-reported household income relative to others in community, working full time, education level, smoking behavior, frequency of attending religious services, and parent(s) receiving a bachelor's degree. All Likert-scale measures are standardized at the individual level ( $z$-scored). $* * * p<0.01, * * p<0.05, * p<0.1$ (bold values indicate significant coefficient upon computing sharpened $q$ values accounting for multiple tests on Afraid of COVID-19 and LDR: $q<0.05)$

\subsubsection{Altruism}

Following Falk et al., (2016, 2018), we measured Altruism via (1) a question about the willingness to give to good causes without expecting anything in return (questions 26), and (2) an (unincentivized) dictator game that asks how to split $\$ 1600$ between oneself and a donation to a good cause (question 33). The measure is then computed as the linear combination of these two responses (applying the weights in 
Table 4 Regression results (Altruism)

Dependent variable: Altruism

\begin{tabular}{|c|c|c|c|c|}
\hline & (a) & (b) & (c) & (d) \\
\hline & Pooled & Wave1 & Wave2 & Wave3 \\
\hline \multirow[t]{2}{*}{ Afraid of COVID-19 } & $3.517^{*}$ & -2.0493 & 3.788 & $11.3543^{* *}$ \\
\hline & $(2.0277)$ & $(3.4346)$ & $(3.94)$ & $(4.7098)$ \\
\hline \multirow[t]{2}{*}{ Local death rate (LDR) } & $0.0868 * *$ & -0.3093 & 0.1835 & 0.0128 \\
\hline & $(0.036)$ & $(0.3027)$ & $(0.1272)$ & $(0.0603)$ \\
\hline \multirow[t]{2}{*}{ Perceive financial hardship (1st PC) } & -0.8035 & 1.0875 & $-3.6922 * *$ & 0.3381 \\
\hline & $(1.4292)$ & $(2.7143)$ & $(1.5367)$ & $(2.319)$ \\
\hline \multirow[t]{2}{*}{ Perceive health hardship (1st PC) } & 1.042 & 0.8126 & -0.9802 & 2.9614 \\
\hline & $(1.6159)$ & $(2.6662)$ & $(1.4844)$ & $(4.4548)$ \\
\hline \multirow[t]{2}{*}{ Female } & 1.4262 & -2.2455 & -2.1227 & 11.1318 \\
\hline & $(4.2254)$ & $(4.7296)$ & $(6.572)$ & $(7.899)$ \\
\hline \multirow[t]{2}{*}{ Good at math } & -2.196 & -4.5329 & 1.1782 & -0.201 \\
\hline & $(2.2596)$ & $(3.4682)$ & $(3.0053)$ & $(3.8492)$ \\
\hline \multirow[t]{2}{*}{ Liberal } & -1.2317 & -1.783 & 1.8997 & -6.391 \\
\hline & $(2.1542)$ & $(3.1088)$ & $(3.3072)$ & $(3.9311)$ \\
\hline \multirow[t]{2}{*}{ Wave 2} & 1.4747 & - & - & - \\
\hline & $(3.1744)$ & & & \\
\hline \multirow[t]{2}{*}{ Wave 3} & 5.7563 & - & - & - \\
\hline & $(3.7076)$ & & & \\
\hline \multirow[t]{2}{*}{ Constant } & 19.7676 & 78.7756 & -6.606 & -29.0264 \\
\hline & $(25.0965)$ & $(47.4807)$ & $(40.5036)$ & $(36.3521)$ \\
\hline Observations & 1484 & 488 & 499 & 497 \\
\hline State fixed effects and additional controls & Yes & Yes & Yes & Yes \\
\hline R-squared (within) & 0.0514 & 0.065 & 0.0725 & 0.0735 \\
\hline
\end{tabular}

Standard errors (clustered at the state level) in parentheses. The dependent variable, Altruism, is computed as the linear combination of questions 26 (willingness to give to good causes without expecting return) and question 33 (dictator game) [Supplementary Material; weights from Falk et al., (2016, 2018)]. Additional controls included age, age-squared, and indicators for race (Caucasian) and origin (Hispanic), self-reported household income relative to others in community, working full time, education level, smoking behavior, frequency of attending religious services, and parent(s) receiving a bachelor's degree. All Likert scale measures are standardized at the individual level ( $z$-scored). $* * * p<0.01$, $* * p<0.05, * p<0.1$

Falk et al., 2016, 2018). Altruism was marginally positively associated with fear of the pandemic (pooled sample: $\beta_{\text {Afraid }}=3.517, p=0.089$ ), and this result was mainly driven by a strong association in the third wave (wave 3: $\beta_{\text {Afraid }}=11.354, p=0.020$ ) (Table 4). Altruism was also significantly associated with LDR (pooled sample: $\beta_{L D R}=0.087, p=0.020$ ) (Table 4 ). These results, however, were not statistically significant when accounting for multiple testing. 
Table 5 Regression results (Positive reciprocity)

Dependent variable: Positive reciprocity

\begin{tabular}{|c|c|c|c|c|}
\hline & (a) & (b) & (c) & (d) \\
\hline & Pooled & Wave1 & Wave2 & Wave3 \\
\hline \multirow[t]{2}{*}{ Afraid of COVID-19 } & 0.3268 & 0.3859 & -0.2894 & 0.5228 \\
\hline & $(0.3812)$ & $(0.518)$ & $(0.6891)$ & $(0.5245)$ \\
\hline \multirow[t]{2}{*}{ Local death rate (LDR) } & -0.0039 & 0.0224 & 0.027 & -0.0097 \\
\hline & $(0.0066)$ & $(0.0628)$ & $(0.0493)$ & $(0.012)$ \\
\hline \multirow[t]{2}{*}{ Perceive financial hardship (1st PC) } & 0.0354 & 0.4281 & -0.1637 & -0.0461 \\
\hline & $(0.1759)$ & $(0.3367)$ & $(0.306)$ & $(0.267)$ \\
\hline \multirow[t]{2}{*}{ Perceive health hardship (1st PC) } & -0.4365 & -0.4633 & -0.5894 & -0.3555 \\
\hline & $(0.3019)$ & $(0.4302)$ & $(0.4856)$ & $(0.5173)$ \\
\hline \multirow[t]{2}{*}{ Female } & 0.2378 & -0.1559 & -0.3339 & $1.7822 *$ \\
\hline & $(0.6241)$ & $(0.7988)$ & $(0.9356)$ & $(1.059)$ \\
\hline \multirow[t]{2}{*}{ Good at math } & -0.2118 & -0.5589 & $-0.8076^{*}$ & 0.6572 \\
\hline & $(0.2819)$ & $(0.4909)$ & $(0.4551)$ & $(0.4007)$ \\
\hline \multirow[t]{2}{*}{ Liberal } & -0.2515 & -0.5949 & 0.5182 & -0.6632 \\
\hline & $(0.2775)$ & $(0.3796)$ & $(0.4689)$ & $(0.455)$ \\
\hline \multirow[t]{2}{*}{ Wave 2} & 0.2964 & - & - & - \\
\hline & $(0.5212)$ & & & \\
\hline \multirow[t]{2}{*}{ Wave 3} & 0.0115 & - & - & - \\
\hline & $(0.6609)$ & & & \\
\hline \multirow[t]{2}{*}{ Constant } & $10.1036^{* *}$ & $17.7464 * *$ & $16.5523 * * *$ & 0.8467 \\
\hline & $(3.9549)$ & $(6.8835)$ & $(5.1743)$ & $(5.5821)$ \\
\hline Observations & 1484 & 488 & 499 & 497 \\
\hline State fixed effects and additional controls & Yes & Yes & Yes & Yes \\
\hline R-squared (within) & 0.0528 & 0.0716 & 0.0778 & 0.0881 \\
\hline
\end{tabular}

Standard errors (clustered at the state level) in parentheses. The dependent variable, Positive reciprocity, is computed as the linear combination of questions 27 (willingness to return favor) and question 34 (gift exchange) [Supplementary Material; weights from Falk et al., (2016, 2018)]. Additional controls included age, age-squared, and indicators for race (Caucasian) and origin (Hispanic), self-reported household income relative to others in community, working full time, education level, smoking behavior, frequency of attending religious services, and parent(s) receiving a bachelor's degree. All Likert scale measures are standardized at the individual level ( $z$-scored). ${ }^{* * *} p<0.01, * * p<0.05, * p<0.1$

\subsubsection{Positive reciprocity}

Neither fear of the pandemic nor LDR were significantly related to Positive reciprocity, measured as the linear combination across questions eliciting willingness to return favors and gift exchange (questions 27 and 34-again applying the weights from Falk et al., 2016, 2018) (Table 5). This lack of association is consistent with previous results indicating weak explanatory power for Positive reciprocity in experimental settings (Charness \& Rabin, 2002). 
Table 6 Regression results (Negative reciprocity)

Dependent variable: Negative reciprocity

\begin{tabular}{|c|c|c|c|c|}
\hline & (a) & (b) & (c) & (d) \\
\hline & Pooled & Wave1 & Wave2 & Wave3 \\
\hline Afraid of COVID-19 & $\begin{array}{l}-0.0764 * * * \\
(0.0204)\end{array}$ & $\begin{array}{l}-0.0989 * * * \\
(0.0351)\end{array}$ & $\begin{array}{l}-0.0905 * * * \\
(0.0316)\end{array}$ & $\begin{array}{l}-0.0412 \\
(0.0388)\end{array}$ \\
\hline Local death rate (LDR) & $\begin{array}{l}0.000008 \\
(0.0004)\end{array}$ & $\begin{array}{l}0.0126 * * * \\
(0.0037)\end{array}$ & $\begin{array}{l}0.0018 \\
(0.0014)\end{array}$ & $\begin{array}{l}0.00002 \\
(0.0007)\end{array}$ \\
\hline Perceive financial hardship (1st PC) & $\begin{array}{l}-0.0218 \\
(0.0144)\end{array}$ & $\begin{array}{l}-0.0436^{*} \\
(0.0225)\end{array}$ & $\begin{array}{l}-0.0231 \\
(0.0211)\end{array}$ & $\begin{array}{l}-0.0012 \\
(0.0188)\end{array}$ \\
\hline Perceive health hardship (1st PC) & $\begin{array}{l}0.0182 \\
(0.0156)\end{array}$ & $\begin{array}{l}0.0122 \\
(0.0294)\end{array}$ & $\begin{array}{l}0.0114 \\
(0.0277)\end{array}$ & $\begin{array}{l}0.0122 \\
(0.028)\end{array}$ \\
\hline Female & $\begin{array}{l}-0.1563 * * * \\
(0.0488)\end{array}$ & $\begin{array}{l}-0.0965 \\
(0.0583)\end{array}$ & $\begin{array}{l}-0.0908 \\
(0.0783)\end{array}$ & $\begin{array}{l}-0.2894 * * * \\
(0.0751)\end{array}$ \\
\hline Good at math & $\begin{array}{l}-0.066^{* * *} \\
(0.0165)\end{array}$ & $\begin{array}{l}-0.0342 \\
(0.0323)\end{array}$ & $\begin{array}{l}-0.0394 \\
(0.0281)\end{array}$ & $\begin{array}{l}-0.1125^{* * * *} \\
(0.0246)\end{array}$ \\
\hline Liberal & $\begin{array}{l}-0.1374 * * * \\
(0.0166)\end{array}$ & $\begin{array}{l}-0.158 * * * \\
(0.0257)\end{array}$ & $\begin{array}{l}-0.1435^{* * * *} \\
(0.026)\end{array}$ & $\begin{array}{l}-0.1129 * * * \\
(0.0301)\end{array}$ \\
\hline Wave 2 & $\begin{array}{l}0.012 \\
(0.0356)\end{array}$ & - & - & - \\
\hline Wave 3 & $\begin{array}{l}-0.0043 \\
(0.0475)\end{array}$ & - & - & - \\
\hline Constant & $\begin{array}{l}-0.0103 \\
(0.2311)\end{array}$ & $\begin{array}{l}0.1115 \\
(0.506)\end{array}$ & $\begin{array}{l}-0.24 \\
(0.3308)\end{array}$ & $\begin{array}{l}-0.0668 \\
(0.3291)\end{array}$ \\
\hline Observations & 1484 & 488 & 499 & 497 \\
\hline State fixed effects and additional controls & Yes & Yes & Yes & Yes \\
\hline R-squared (within) & 0.1455 & 0.1988 & 0.154 & 0.1609 \\
\hline
\end{tabular}

Standard errors (clustered at the state level) in parentheses. The dependent variable, Negative reciprocity, is computed as the linear combination of questions 24 (willingness to punish who treats you unfairly), question 25 (treat others unfairly), and question 28 (taking (costly) revenge when treated unjustly) [Supplementary Material; weights from Falk et al., (2016, 2018)]. Additional controls included age, agesquared, and indicators for race (Caucasian) and origin (Hispanic), self-reported household income relative to others in community, working full time, education level, smoking behavior, frequency of attending religious services, and parent(s) receiving a bachelor's degree. All Likert scale measures are standardized at the individual level ( $z$-scored). $* * * p<0.01, * * p<0.05, * p<0.1$ (bold values indicate significant coefficient upon computing sharpened $q$ values accounting for multiple tests on Afraid of COVID-19 and LDR: $q<0.05$ )

\subsubsection{Negative reciprocity}

We also compute Negative reciprocity as the linear combination across three questions eliciting willingness to punish unfairness or to take revenge (questions 24, 25 and 28-again applying the weights from Falk et al., 2016, 2018). We find a negative and significant association between Negative reciprocity and fear of the pandemic (pooled sample: $\beta_{\text {Afraid }}=-0.076, p<0.001$, sharpened $q$ value $=0.007$ ), with 
the effect fading across waves (wave 1: $\beta_{\text {Afraid }}=-0.099, p=0.007$, sharpened $q$ value $=0.026$; wave 2: $\beta_{\text {Afraid }}=-0.090, p=0.006$, sharpened $q$ value $=0.026$; wave 3: $\beta_{\text {Afraid }}=-0.041, p=0.293$ ) (Table 6). Interestingly, in our first wave, LDR was significantly and positively associated with Negative reciprocity (wave 1: $\beta_{L D R}$ $=0.0126, p=0.001$, sharpened $q$ value $=0.010$ ). This suggests that during the initial stages of the pandemic, participants who resided in counties with high deaths per capita may have become less forgiving of selfish behavior. We find similar associations between our generalized measure of the intensity of experiencing the pandemic and Altruism, Positive reciprocity, and Negative reciprocity (Supplementary Material).

\section{Discussion}

We document changes in economic preferences and their covariation with selfreports of fear, during the early weeks of the COVID-19 crisis in the United States. Our findings point to a negative and significant relationship between respondents' willingness to take risks or delay rewards and their self-reported fear of the pandemic. We also find a positive relationship between Altruism and fear of the pandemic, while Negative reciprocity decreases with higher fear.

One limitation of our study is the reliance on repeated cross sections, thus we are circumspect about causal inferences. We attempt, however, to establish the robustness of our findings by including a comprehensive set of individual controls, and we supplement our findings with additional data from our university panel sample (Supplementary Material). Another limitation is that we investigate changes over a short period of time; further research is warranted to identify longer term impacts of the pandemic. Finally, our measures of economic preferences were not incentivized, though recent studies suggest that self-reported preferences can have high test-retest reliability (Arslan et al., 2020; Frey et al., 2017; Mata et al., 2018).

Our results have implications for experimental research. Large scale events such as pandemics and natural disasters can cause shifts in economic preferences, and these changes may evolve over time as an event continues. Thus, skepticism of results from experiments where treatments are carried out at different times during a crisis may be warranted. Estimates from preferences elicited prior to a given crisis may also not be ideal for predicting behavior during the crisis. On the other hand, these results show that not all preferences were affected by the pandemic. We encourage researchers conducting experiments on decision-making during the pandemic (or other crises) to measure and control for personal experience. As we demonstrate with fear of the pandemic, emotional experiences may systematically influence preferences and behavior. To capture the effect of significant events in general, and of the COVID-19 pandemic in particular, it is important to develop, refine, and administer indices of emotional experiences, such as the fear of COVID-19 scale (Ahorsu et al., 2020). Such data make it possible to carefully consider the context in which preferences are measured.

Understanding the links between economic preferences and fear of COVID-19 is also helpful for developing public health policy. Effective public health strategies 
are essential for identifying effective policies to mitigate the effect of the pandemic and communicate with the public. Our study suggests that reducing fear may create positive economic spillovers, encouraging risk-taking, cooperation, and investment. Policies that promote trust in the government, or at least avoid creating distrust, may be helpful in reducing fear.

Supplementary Information The online version contains supplementary material available at https://doi. org/10.1007/s40881-021-00111-x.

Funding Funding provided by the Virginia Tech Department of Economics and by National Science Foundation (\#1541105).

Data availability Upon publication, data will be made available via the Open Science Framework at https://osf.io/drhfw.

Code availability Upon publication, analysis script will be made available via the Open Science Framework at https://osf.io/drhfw.

\section{Declarations}

Conflict of interest The authors declare that they have no conflicts of interest or competing interests.

\section{References}

Ahorsu, D. K., Lin, C.-Y., Imani, V., Saffari, M., Griffiths, M. D., \& Pakpour, A. H. (2020). The fear of covid-19 scale: development and initial validation. International Journal of Mental Health and Addiction. https://doi.org/10.1007/s11469-020-00270-8

Allcott, H., Boxell, L., Conway, J., Gentzkow, M., Thaler, M., \& Yang, D. (2020). Polarization and public health: partisan differences in social distancing during the coronavirus pandemic. Journal of Public Economics, 191, 104254.

Alsharawy, A., Spoon, R., Smith, A., \& Ball, S. (2021). Gender differences in fear and risk perception during the covid-19 pandemic. Frontiers in Psychology, 12, 3104. https://doi.org/10.3389/fpsyg. 2021.689467

Anderson, M. L. (2008). Multiple inference and gender differences in the effects of early intervention: a reevaluation of the abecedarian, perry preschool, and early training projects. Journal of the American Statistical Association, 103(484), 1481-1495.

Arslan, R. C., Brümmer, M., Dohmen, T., Drewelies, J., Hertwig, R., \& Wagner, G. G. (2020). How people know their risk preference. Scientific Reports, 10(1), 1-14.

Barrios, J. M., \& Hochberg, Y. (2020). Risk perception through the lens of politics in the time of the covid-19 pandemic (No. 0898-2937). National Bureau of Economic Research. https://doi.org/10. 3386/w27008

Beine, M. A., Charness, G., Dupuy, A., \& Joxhe, M. (2020). Shaking things up: on the stability of risk and time preferences. CESifo Working Paper No. 8187, Available at SSRN 3570289

Bu, D., Hanspal, T., Liao, Y., \& Liu, Y. (2020). Risk taking during a global crisis: evidence from Wuhan. Covid Economics, 5, 106-146.

Callen, M. (2015). Catastrophes and time preference: evidence from the indian ocean earthquake. Journal of Economic Behavior \& Organization, 118, 199-214. https://doi.org/10.1016/j.jebo.2015.02.019

Callen, M., Isaqzadeh, M., Long, J. D., \& Sprenger, C. (2014). Violence and risk preference: experimental evidence from Afghanistan. American Economic Review, 104(1), 123-148.

Cassar, A., Healy, A., \& Von Kessler, C. (2017). Trust, risk, and time preferences after a natural disaster: experimental evidence from Thailand. World Development, 94, 90-105. 
Charness, G., \& Rabin, M. (2002). Understanding social preferences with simple tests. The Quarterly Journal of Economics, 117(3), 817-869.

Coelho, C. M., Suttiwan, P., Arato, N., \& Zsido, A. N. (2020). On the nature of fear and anxiety triggered by COVID-19. Frontiers in Psychology, 11, 3109.

DeSteno, D., Li, Y., Dickens, L., \& Lerner, J. S. (2014). Gratitude: a tool for reducing economic impatience. Psychological Science, 25(6), 1262-1267.

Dohmen, T., Falk, A., Huffman, D., Sunde, U., Schupp, J., \& Wagner, G. G. (2011). Individual risk attitudes: measurement, determinants, and behavioral consequences. Journal of the European Economic Association, 9(3), 522-550.

Dong, E., Du, H., \& Gardner, L. (2020). An interactive web-based dashboard to track covid-19 in real time. The Lancet Infectious Diseases, 20(5), 533-534.

Eckel, C. C., El-Gamal, M. A., \& Wilson, R. K. (2009). Risk loving after the storm: a Bayesian-network study of hurricane katrina evacuees. Journal of Economic Behavior \& Organization, 69(2), $110-124$.

Eckel, C. C., \& Grossman, P. J. (2002). Sex differences and statistical stereotyping in attitudes toward financial risk. Evolution and Human Behavior, 23(4), 281-295. https://doi.org/10.1016/S10905138(02)00097-1

Esaiasson, P., Sohlberg, J., Ghersetti, M., \& Johansson, B. (2021). How the coronavirus crisis affects citizen trust in institutions and in unknown others: evidence from 'the Swedish experiment.' European Journal of Political Research, 60(3), 748-760.

Falk, A., Becker, A., Dohmen, T., Enke, B., Huffman, D., \& Sunde, U. (2018). Global evidence on economic preferences. The Quarterly Journal of Economics, 133(4), 1645-1692.

Falk, A., Becker, A., Dohmen, T. J., Huffman, D., \& Sunde, U. (2016). The preference survey module: a validated instrument for measuring risk, time, and social preferences. SSRN. https://doi.org/10.2139/ ssrn. 2725874

Fleming, D. A., Chong, A., \& Bejarano, H. D. (2014). Trust and reciprocity in the aftermath of natural disasters. The Journal of Development Studies, 50(11), 1482-1493.

Frey, R., Pedroni, A., Mata, R., Rieskamp, J., \& Hertwig, R. (2017). Risk preference shares the psychometric structure of major psychological traits. Science Advances, 3(10), e1701381.

Gadarian, S. K., Goodman, S. W., \& Pepinsky, T. B. (2021). Partisanship, health behavior, and policy attitudes in the early stages of the covid-19 pandemic. PLOS ONE, 16(4), e0249596. https://doi.org/ 10.1371/journal.pone.0249596

Gambetta, D., \& Morisi, D. (2020). L'Enfer c'est les Autres? The effects of covid-19 virus on interpersonal trust. SocArXiv. https://doi.org/10.31235/osf.io/rm4ck

Guiso, L., Sapienza, P., \& Zingales, L. (2018). Time varying risk aversion. Journal of Financial Economics, 128(3), 403-421.

Hanaoka, C., Shigeoka, H., \& Watanabe, Y. (2018). Do risk preferences change? Evidence from the great east Japan earthquake. American Economic Journal: Applied Economics, 10(2), 298-330. https:// doi.org/10.1257/app.20170048

Huang, L., Zhou, Y., Han, Y., Hammitt, J. K., Bi, J., \& Liu, Y. (2013). Effect of the Fukushima nuclear accident on the risk perception of residents near a nuclear power plant in China. Proceedings of the National Academy of Sciences, 110(49), 19742-19747.

Ibuka, Y., Chapman, G. B., Meyers, L. A., Li, M., \& Galvani, A. P. (2010). The dynamics of risk perceptions and precautionary behavior in response to 2009 (H1N1) pandemic influenza. BMC Infectious Diseases, 10(1), 1-11.

Ifcher, J., \& Zarghamee, H. (2011). Happiness and time preference: the effect of positive affect in a random-assignment experiment. American Economic Review, 101(7), 3109-3129.

Inglehart, R., Basáñez, M., Díez-Medrano, J., Halman, L., \& Luijkx, R. (2004). Human beliefs and values: a cross-cultural sourcebook based on the 1999-2002 values surveys. Mexico: Siglo XXI.

Jang, W. M., Kim, U.-N., Jang, D. H., Jung, H., Cho, S., Eun, S. J., \& Lee, J. Y. (2020). Influence of trust on two different risk perceptions as an affective and cognitive dimension during middle east respiratory syndrome coronavirus (MERS-CoV) outbreak in South Korea: serial cross-sectional surveys. British Medical Journal Open, 10(3), e033026.

Lee, S. A., Mathis, A. A., Jobe, M. C., \& Pappalardo, E. A. (2020). Clinically significant fear and anxiety of COVID-19: a psychometric examination of the coronavirus anxiety scale. Psychiatry Research, 290, 113112.

Lerner, J. S., Li, Y., \& Weber, E. U. (2012). The financial costs of sadness. Psychological Science, 24(1), 72-79. https://doi.org/10.1177/0956797612450302 
Loewenstein, G. F., Weber, E. U., Hsee, C. K., \& Welch, N. (2001). Risk as feelings. Psychological Bulletin, 127(2), 267-286. https://doi.org/10.1037/0033-2909.127.2.267

Malmendier, U., \& Nagel, S. (2011). Depression babies: do macroeconomic experiences affect risk taking? The Quarterly Journal of Economics, 126(1), 373-416.

Mata, R., Frey, R., Richter, D., Schupp, J., \& Hertwig, R. (2018). Risk preference: a view from psychology. Journal of Economic Perspectives, 32(2), 155-172.

Painter, M., \& Qiu, T. (2020). Political beliefs affect compliance with covid-19 social distancing orders. SSRN. https://doi.org/10.2139/ssrn.3569098

Public Trust in Government: 1958-2021 (Pew Research Center-U.S. Politics \& Policy). (2021). Pew Research Center. https://www.pewresearch.org/politics/2021/05/17/public-trust-in-government1958-2021/. Accessed 4 Oct 2021

Shachat, J., Walker, M. J., \& Wei, L. (2021). How the onset of the covid-19 pandemic impacted prosocial behavior and individual preferences: experimental evidence from China. Journal of Economic Behavior \& Organization, 190, 480-494. https://doi.org/10.1016/j.jebo.2021.08.001

Shah, A. (2020). ASDOC: stata module to create high-quality tables in MS word from stata output. Statistical software components. Boston: Boston College Department of Economics.

Stein, J. Y., Levin, Y., Gelkopf, M., Tangir, G., \& Solomon, Z. (2018). Traumatization or habituation? A four-wave investigation of exposure to continuous traumatic stress in Israel. International Journal of Stress Management, 25(S1), 137.

Stigler, G. J., \& Becker, G. S. (1977). De Gustibus Non est Disputandum. The American Economic Review, 67(2), 76-90.

Taylor, M. R., Agho, K. E., Stevens, G. J., \& Raphael, B. (2008). Factors influencing psychological distress during a disease epidemic: data from Australia's first outbreak of equine influenza. BMC Public Health, 8(1), 1-13.

U.S. Bureau of Labor Statistics, Employment Level [CE16OV]. (n.d.). retrieved from FRED, Federal Reserve Bank of St. Louis. From https://fred.stlouisfed.org/series/CE16OV. Accessed 20 Oct 2021

Wagner, G. G., Frick, J. R., \& Schupp, J. (2007). The German socio-economic panel study (SOEP)-evolution, scope and enhancements. SSRN Electronic Journal. https://doi.org/10.2139/ssrn.1028709

Whitt, S., \& Wilson, R. K. (2007). Public goods in the field: Katrina evacuees in houston. Southern Economic Journal, 74(2), 377-387. https://doi.org/10.2307/20111973

Publisher's Note Springer Nature remains neutral with regard to jurisdictional claims in published maps and institutional affiliations. 